\title{
Methodologies for Collaborative, Respectful and Caring Research: Conversations with Professional Indigenous Women from Mexico
}

\section{Marina Cadaval Narezo}

\section{Setting Common Ground}

In this chapter I share the methodological process that I have followed throughout my doctoral research. It focuses on learning about and reflecting on the expectations related to graduate education and the consequent professional and community journeys of a group of Indigenous women from Mexico. ${ }^{1}$ I met them several years ago, when they obtained a scholarship to carry out master's and doctoral studies in

${ }^{1} \mathrm{My}$ Ph.D. research is done from the International Institute of Social Studies of the Erasmus University Rotterdam (ISS-EUR), The Netherlands.

M. Cadaval Narezo $(\bowtie)$

International Institute of Social Studies, Erasmus University Rotterdam, The Hague, The Netherlands

e-mail: cadavalnarezo@iss.nl

(C) The Author(s) 2022

W. Harcourt et al. (eds.), Feminist Methodologies,

Gender, Development and Social Change, https://doi.org/10.1007/978-3-030-82654-3_7 
the first initiative to allow original peoples ${ }^{2}$ to pursue graduate degrees. Financially supported from 2001 to 2012 by the Ford Foundation as the International Fellowships Program (IFP), and from 2013 onwards by the federal government as the Graduate Scholarship Program for Indigenous People (Probepi), ${ }^{3}$ I worked for both along more than 10 years. Although the grants were for both men and women, my interest has focused on the stories and experiences of the latter because of the deeper exclusions they undergo due to the intersections of race, gender and class.

At IFP-Probepi, my responsibilities - first as a program officer and later as an executive coordinator-required becoming involved in the entire operational process, interacting with candidates who became selected fellows, degree students and alumni. The small work team was made up of five members. As most of us worked there from the beginning to the end of IFP and some changes were made from 2013, we were all familiar with the whole implementation. This process included designing dissemination campaigns, organizing selection committees, setting up pre-academic courses. We worked together with the fellows to find M.A. and Ph.D. programs and universities that suited their professional interest, monitoring student's performances and organizing alumni workshops and activities. It was during that decade of interacting with hundreds of Indigenous women that a series of concerns-discomforts-arose in me, resulting from first-hand knowledge of the stories of those who applied for a scholarship. These were stories from women who had been the first in their families or in their communities to go to university; women who as girls had to attend primary schools in boarding schools far from home, in other regions, in other states. Women whose stories were sometimes products of collective efforts, sometimes solitary struggles, generally painful, complex processes.

For them, the dream of completing a degree meant an opportunity, but also a multi-pronged challenge. On the one hand, the academic world presented them with the difficulty of meeting standards higher than the educational system had offered them throughout their schooling. Challenges continued with discrimination by virtue of taking up room, or

\footnotetext{
${ }^{2}$ I will use the term "Indigenous" or "original peoples" interchangeably as both are equally used by the research participants.

${ }^{3}$ Probepi has been sponsored by the National Council of Science and Technology (CONACYT). Both programs have been administered and executed by the Centre for Research and Higher Education in Social Anthropology (CIESAS).
} 
“invading” according to Puwar (2004), university spaces unaccustomed to Indigenous bodies, knowledges and methodologies. On the other hand, pursuing education also meant breaking with "obligations" of their communities-marrying, having children, making tortillas. ${ }^{4}$ What would happen to them when they returned from their masters and doctorates? In a country like Mexico, wounded by its colonial history (Mignolo, 2011), inherently racist, sexist and classist, would having a solid academic career make a difference? Would they be accepted in their communities-women breaking stereotypes? Would they find more or better opportunities for professional development-women historically excluded from the system?

To answer these questions, as a feminist researcher, I thought that the most appropriate thing to do was to ask them directly. Talk it over. I had met them at an important stage in their lives. I got to know them perhaps in one of the program's dissemination talks, or in the workshops to apply for the IFP-Probepi scholarships, or during the interview processes. Surely I met them through the course of their three or four year journey as students, as alumni and some of them as members of the program's selection committees. ${ }^{5}$ Surveys and interviews would not be enough or even adequate. I believe in methodological approaches that are anti-oppressive (Brown \& Strega, 2005), based on "other practices" that challenge Western knowledge production (Smith, 2012), and that seek to promote relationships of reciprocity, collaboration and mutual recognition (Wilson, 2008). Therefore, using only conventional methods (surveys, interviews) would be incongruous, even disrespectful with what I understand as feminist's ways of knowledge production. By this I mean

\footnotetext{
${ }^{4}$ According to many of the stories shared by IFP-Probepi fellows, knowing how to make them is a symbol of femininity and family bonding as corn tortillas are the main product in a Mexican households' meal.

${ }^{5}$ IFP-Probepi offers a series of supports and activities that involve a long and consistent collaboration between fellows and administrative staff. In addition to financial resources to cover university fees and living expenses, it considers up to one year of academic courses prior to the start of the graduate programs. It also provides advice and management to identify and apply to universities and programs related to the interests of the selected fellows. During the studies, a close, individualized monitoring is done to accompany them until they obtain their degrees. Follow-up activities, professional reintegration workshops and academic fora have been organized for graduates. Several alumni have been part of the program's selection committees. All these processes imply a close and long-term relationship between all the parties involved, from administrative and executive staff, to the students and alumni themselves.
} 
positioned practices that recognize and assume the individual and collective responsibilities implied. Practices-reflective and narrative-that are not exempt from inconsistencies in the representations produced, but which, when assumed, locate the arguments from that imperfection, depicting complex realities and intricate power relations in the production of knowledge.

To talk about feminist methodologies is, for me, to recognize that thought is collective and contextual, in time, in space, in circumstances. It is also about sharing. It is about time. Time to dialogue-with the participants and collaborators, with oneself-to digest, to marinate the ideas and perspectives from where to reflect, question and transform the social problem we are looking at. My methodological journey, hence, has entailed a constant exercise of reflection-confrontational and questioning - on the implications that producing knowledge implies. It has required paying attention to the forms, to the substance, the background, the contexts, the personal and collective interests, to temporalitiesthe ephemerality of an encounter and the permanency of a memory; to the vulnerability of shared emotions. It required fluency. It required care. Caring not as frailty, but quite the opposite. Caring to generate partial and situated knowledges (Haraway, 1988; Harding, 1991), which contributes with the strength, conviction and clarity to the methodological and epistemic mosaic that intersectional feminist proposals (Crenshaw, 1989; Collins, 2000; Hooks, 2015), as well as Indigenous and decolonial (Brown \& Strega, 2005; Smith, 2012; Walsh et al., 2002; Wilson, 2008) have inspired.

That is why, looking to find a common ground with the participants of the research, I used what I have called "reflective conversations" 6 : discussions, encounters that depart from common and mutual understandings - the IFP-Probepi but also the graduate studies or our diverse feminisms - through which we find and examine ourselves in multiple times and spaces. Through conversation I was looking for a link beyond obtaining information, systematizing it and presenting it as a final and individual product. I wanted us to look at each other, to recognize who

\footnotetext{
${ }^{6}$ I have not found much literature that deepens or describes this method. Morgan's work Beyond Method (1983) mentions the importance of conducting critical conversations between researchers and participants as an epistemic and methodological basis for the "scientific method", from which plural perspectives are promoted.
} 
we were and who we are; that they knew me not only as the program officer and the executive coordinator of IFP-Probepi with whom they worked on logistical issues, but the researcher interested in understanding and shedding light on their struggles and resistances.

The research was the initial motivation to contact them again. The process itself required several meeting points: first by e-mail and other electronic means to share my objectives; later, in personal encounters in their communities or places of residence. Afterwards, in group virtual meetings, in which I shared the preliminary findings from those face-toface conversations: individual talks that resulted in some-unexpectedcoincidences that I thought worthy to be discussed in groups. And finally, an ongoing, permanent process of sharing texts produced with the protagonists involved. This last process has implied that I write in Spanish (our common language), receive feedback, adjust their suggestions, have their approval to publish, etc. It has been a feminist, collaborative approach that has required time, trust and care.

After considering an initial framing to develop my research, I contacted 36 IFP-Probepi alumni who completed their graduate studies between 2002 and 2014 (out of a total of 71 until 2015), explaining the objectives, scope and implications of my Ph.D. project. With the intention of having a diverse group, I invited women from different Indigenous groups and states, as well as with diverse academic interests and understandings of community belonging. Such understandings vary depending on multiple circumstances, such as if they had to migrate from their villages, towns or regions of origin; or those whose parents are from two different Indigenous groups, etc. The final group was made up of 17 of them: three Maya women from Yucatan; one Nu Savi woman (Mixteca), six Zapotec women and one Huave woman from Oaxaca; two Nahua women from Veracruz; one Chol woman, one Tseltal woman and one Tsotsil woman from Chiapas; and one Rarámuri woman from Chihuhua. Their areas of specialization are Sociology, Gender, Law, Anthropology, Education, Agronomy and Rural Development, among others. Some completed their degrees more than ten years ago and the most recent one did so in 2014 . Their current age ranges vary between 25 and 57 years, and the age range when they completed their degrees was between 24 and 40 years; two of them were mothers then and four others had children later on (in total 6 
of the 17 are currently mothers). ${ }^{7}$ Two did Ph.D.s' and fifteen of them pursued master's degrees. The majority studied outside of Mexico and those that stayed in the country, moved outside their states or regions of origin. Three did not complete their (master's) degrees. Their inclusion in the group was deliberate in order to know and understand their motives, as well as the implications on a personal and professional level. They are fundamental stories to look at and to disentangle the intersections between race, gender and class that should inform educational policies directed at racialized women.

While working at IFP-Probepi, I was closer with some than with others. I would dare to say that in general there was mutual respect and, in some cases, mutual affection and care. Therefore, the methodological process of the research started from those bonds of respect, affection and care. In this chapter I will describe how respect, caring and collaboration played a valuable methodological role. They allowed me not only to understand in a much clearer way their paths, the importance of the IFPProbepi in their journey and to address my research questions, but also to build knowledge that goes beyond the very objective of writing a doctoral thesis, and is more closely linked to the reality we want to transform.

I present two encounters that, on the one hand, reflect these three elements-respect, affection and caring-in the process to build my research, and on the other, they are a sample of diverse narratives or "texts-in-context" (Willemse, 2014) resulting from the same methodological process. They are narratives that represent and happen at a certain time and in a certain space. They imply changing positions, not only due to the political, social, economic, religious variations of a place that are modified and modify us (Willemse, 2014), but also due to our own individual journeys that lead us to reflect or see differently. The two encounters took place in the cities of residence of each participant. One in Oaxaca city and the other in Valladolid, in the state of Yucatan. Meeting in the cities was important to talk in spaces that are familiar to them and

\footnotetext{
${ }^{7}$ Motherhood and/or the formation of a family is an important aspect to mention, since it is part of the tensions that several participants mentioned. The dynamics of professional development, the expectations that their communities and families have about them as women, and "the lack of candidates [potential partners] who are not afraid of me" as one of them said, is an equation not easy to solve for most women in Mexico.
} 
in which they felt confident, as well as for me to understand and contextualize some of their professional and personal dynamics. Although neither live directly in their communities of origin, they reside in the same state and in the same region. The meaning, the sense of belonging travels, is not fixed, is wide but concrete (Aguilar Gil, 2020).

Before going into the stories, I would like to pinpoint something about my narrative inspired by the recognition that Wilson (2008) makes of the relationship between his own research as a Canadian Indigenous person and his readers. He speaks of the difficulty of finding a middle ground between those who do not know the contexts, the meanings or the backgrounds portrayed-for which it is necessary to dedicate more time and describe in greater detail what is intended to transmit-and those for whom too many explanations or details could be seen as a lack of respect to their intelligence (Wilson, 2008: 7). My own writing process in these pages has straddled these same tensions. When I write, I think of the participants with whom I have shared the drafts and for whom so much contextual clarification is unnecessary. I also think of international readers who do not know the reality that I seek to describe. I apologize for the inconsistencies that this entails. I hope the balance is respectful to everyone.

The texts I am sharing are brief and different in terms of what they narrate, but also in their rhythms, their contents, their extensions, the analytical elements they offer, and even of the times they were written. Their form is an example and a reflection of our conversations and of my own process of critical reflexivity (Rose, 1997), from which I assume the uncontrollable effect of the incongruences, absences and failures implied. At the beginning of each one, I explain how and when I wrote them as well as reflecting on my own motivation for writing. At the end of the two stories, I try to weave some of those elements together that are valuable in a methodological process that seeks care and respect as central to the production of knowledge. The reflections are shared and collective, the narrative is mine. 


\section{The NARratives}

\section{Marcela. The Food and the Microbus ${ }^{8}$}

After having lunch at a restaurant near Marcela's work in Oaxaca city where we began our conversation, we went together by micro 9 to our respective destinations. She went home to prepare for the next day's trip to the neighbouring state of Chiapas in her role as inspector of organic products in rural communities. I at the hotel where I had come to meet other IFP-Probepi alumni to discuss my research. Our route, up to a point, was the same. We accompany each other. We take care of each other. The food was as a preamble to talk a little about everything and nothing, about our health, about food, about sexism in Mexico. Despite the differences that separate us, the dissimilar stories that have forged us, we also have coincidences and empathies that unite us: the difficult journey of graduate studies, our diverse feminisms, our anti-racist positions. And it is from there that our conversation was built.

The restaurant where we met turned out to be close to Marcela's work. I suggested it but she knew it well. A simple fonda ${ }^{10}$ run by Doña Luz, ${ }^{11}$ a Tehuana woman ${ }^{12}$ who, while cooking, served us, and continuously interrupted our conversation-in a very casual, friendly way-to tell a little about each dish, about her colourful clothing, about her personal history. At one point she sat down with us and joined our reflections. We were commenting on some of the problems in Marcela's community when Doña Luz referred to the Indigenous people of the Isthmus of Tehuantepec with distance and with a certain condescension and a patronizing tone. Marcela and I looked at each other with complicity, not saying anything, we silently understood the complexities of the sense of identity.

${ }^{8}$ The quotes in this narrative correspond to the reflective conversation with Marcela Avella. Oaxaca, Mexico, November 19, 2019 (audio).

${ }^{9}$ Microbuses, peseros or colectivos in Mexico are the most used public transport, generally characterized by their poor condition, and the careless driving of the drivers. They cost between $\$ 3$ and $\$ 10$ pesos (\$0.15-\$0.50 USD) depending on the region and the distance travelled.

${ }^{10}$ Fondas are local restaurants characterized by homemade food, normally prepared by the same owners, who also attend the costumers.

${ }^{11}$ I use a pseudonym to respect the anonymity of the women involved in the narrative.

12 Originally from the Isthmus of Tehuantepec, a Zapotec region known, among other things, for the strong presence of merchant women, who proudly wear beautiful petticoats and colourful huipiles (embellished blouses or dresses). 
Tehuanas like Doña Luz are Zapotec, "Indigenous" if we use one of the official terms to name and group the original peoples. ${ }^{13}$ However, she did not identify as such. That moment, that comment, our crossed gazes led Marcela and me to reflect on the subject later. The place mattered, the physical space of our encounter helped to contextualize the conversation, for the ideas to flow and for us to find various references from which to bridge and connect our ideas.

During the trip in the pesero, having already addressed all the issues related to my research, the recorder turned off, ${ }^{14}$ our hearts met in memories that were also part of that present, and other reflections arose. In the brief story that I share below, that transition between ideas and spaces that allowed us to talk in a loose, deep and respectful way is reflected. The text weaves my narrative with Marcela's stories and words. It provides some analytical elements around topics such as the relevance of graduate education and identity tensions that are valuable for discussing the intersections between gender, race and class in higher education, but which are not the reason for this chapter. I wrote the text immediately after meeting Marcela, inspired and excited to have spent a warm afternoon with her (physically and emotionally speaking). It was a reunion that has kept us close.

\section{Oaxaca, November 19, 2019}

\section{Microbus Conversations}

At age 11, Marcela was looking for the moon from the window of the room she shared with many other girls at the boarding school she went to in Puebla, $460 \mathrm{kms}$ away from Tanetze de Zaragoza, her hometown in Oaxaca. She asked for, or got the farthest bed, the one in the corner, the one that overlooked that window that allowed her to look at her

${ }^{13}$ Mexico has 68 groups that represent $20 \%$ of the total population (more than 25 million people). Although they live throughout the country, the Southeast region has the highest concentration. Only between Oaxaca and Chiapas live almost $30 \%$ of the total of the Indigenous persons. Oaxaca is the state with more groups, 16 different groups representing $14.4 \%$ of the total of the Indigenous population of the country (El Economista, 2018).

${ }^{14}$ At the beginning of each of the 17 conversations carried on, I asked for authorization to record them, justifying the importance for my reflective process. To do so, I followed the ISS-EUR ethical protocols (https://www.iss.nl/en/research/research-excellence/res earch-ethics). 
parents through the moon. Every night she looked at it for a long time, whether full, waning or new. For her, the moon was a convex reflector that transported her to her village, where she imagined her parents also looking up at it. She portrayed them mirroring her lying on the bed, scared, and they comforted her by talking in silence. It was not a cliché. Neither she nor her parents, as in a novel, had agreed to meet on the moon to close the distance. For Marcela this was a concrete fact, a practice that ran in her Zapotec blood, and at that moment she used it to find love and care. It was a way of feeling accompanied and making sense of the need to study so far away from home.

When she was interviewed for the IFP scholarship in 2002 to do graduate studies in Rural Development, the selection committee members asked her if she thought she had leadership skills. Marce said that she would be the first woman in her town to do a master's degree if she got the scholarship. She didn't know if they would understand and translate what that meant, if they would have the faintest idea about her academic trajectory. She also wasn't sure if that was a good answer, but that was the only thing that passed through her mind.

With the first sip of coffee that Doña Luz served us, Marcela immediately recognized: it has cardamom. "How can you tell?" I asked surprised and embarrassed by my lack of palate.

I am a producer and coffee taster. It's my personal project with my mom and dad. We even have our own strain! Coffee allowed us to become commoners with hearts of small landowners - she laughed-although our family project has influenced the community. Several families have resumed planting and selling coffee that had been lost due to lack of resources. I have helped them manage support from the government and other institutions to get grain and machinery. (Avella, 2019)

Although she lives in Oaxaca city, where she works as an inspector of organic products, her family-personal-community project is in Tanetze, with her coffee plantations: "I dream of selling coffee in my town and that tourists go there, get to know the region and learn from the people. That they enjoy our coffee" (Avella, 2019).

While the micro took us from the Yunenisa restaurant, where Doña Luz's food triggered contextualized reflective discussions to the centre of Oaxaca city, Marce delved into what could be interpreted as leadership. She wondered, what it meant for an 11-year-old girl to agree to go 
to a boarding school in another state, $460 \mathrm{kms}$ away, to continue with secondary school. I think she had not seen it so clearly until then. There we were, sharing memories in the old and dilapidated micro with broken and open windows allowing the air to reduce the heat; with reggaeton at full volume, a ventriloquist doing his act looking to get some pesos, and the potholes that shook us in all directions. It was there where she realized and accepted that since she was a child, she has had a fierce spirit.

"I was always like that, decisive" (Avella, 2019). She laughs. We laugh. I recognized myself as decisive too and shared with her personal experiences that led us to discuss how, in a patriarchal society like Mexico, to be determined is not a very feminine characteristic. Quite the opposite. We laughed, I think, recognizing our transgression. Proud of it, acknowledging the implied tensions. Although her parents went to visit her three months after she left, a little because she had chickenpox, and a lot because they wanted her back, it was she who decided to stay. Her heart broke too, but she imagined some members of the family saying "obviously, you couldn't make it," and her pride gave her the strength to send her parents back, confused and devastated. That was, she realized while we were conversing, the beginning of her strong and decisive spirit. The one that has always accompanied her, the one that the members of the selection committee probably saw and with which she takes advantage of the opportunities she finds, and the ones that she also creates.

She smiles complicitly when she tells me how men-and women-are amazed when they see her driving. She knows well that by taking the steering wheel of the vocho ${ }^{15}$ that she bought with the earnings from her job she breaks with all the stereotypes imposed on her: those of her people and other communities in the region and according to whom she should be at home with her husband and children; and those that come out of mestizo and white people's looks, for whom, in addition to being at home surrounded by children, it is assumed it would be difficult for her to have finished primary school-therefore being able to know how to drive or to have the economic means to buy a car. "I have a vehicle, degrees and I participate in the assembly, and with those three I have enough so that they do not accept me" (Avella, 2019). The laughter intensifies -hers, mine. Our connection continues to grow. In my own trajectory as a middle class, urban woman-I feel-the sexism is the same. The details are different.

${ }^{15}$ This is how the Volkswagen sedan model is called and that was the most accessible vehicle in Mexico until 2003, when it was discontinued. 
We said goodbye in the pesero. She got off before me. I stayed with the reggaeton, the shaking and the immense satisfaction of having met her again, of having shared valuable reflections to understand the complexities and tensions that being a professional Indigenous woman means. But above all I was pleased for having confirmed that we are women looking to promote dynamics and spaces of inclusion, respect and equality. In some way we agreed, even without naming it as such, that we live what writer Sarah Ahmed calls "a feminist life" (2017). That is, in our daily actions, in the way we understand and relate with others and within our own surroundings, we challenge and discuss the structural sexism that still oppresses.

How do I link this narrative to my understanding of a feminist methodology? I think that, in one way it was an encounter of sharing, caring, bonding, thinking together. A space, a moment where we coincided and reflected on topics that I was interested in for my research, but that Marcela said she thinks about all the time. She told me she was happy to find someone with whom to discuss, lean on, complain, laugh about those thoughts, her experiences. To remember part of who she is and recognize the value of her professional trajectory: important reflections for the self-esteem. On the other hand, the narrative itself and the possibility of publishing a chapter that includes our encounter became an excuse to continue discussing the text in distance, as I am back in The Netherlands. Some of the writing has been done while drinking Marcela's coffee BI'AVELLA that I brought from my last trip to Mexico at the end of 2020. Academic processes that go beyond doing a research and are more connected to the reality we live in, that we question and want to transform. Relationships, processes built from and with care.

\section{Miriam. The Market and the Cenote ${ }^{16}$}

I am writing this text in April 2020, six months after having seen Miriam. We are in the middle of the Covid-19 crisis that spilled over several weeks ago. I am in The Hague, in The Netherlands, locked up at home, working. The most fluid and inspiring way to review the conversations with the participants of my research is to listen to them while walking in the woods that are close to where I live. I review the audios recorded while conversing, and I go back to the exact moment of our encounter.

\footnotetext{
${ }^{16}$ The quotes in this narrative correspond to the reflective conversation with Miriam Uitz. Valladolid, Yucatan, Mexico, October 9, 2019 (audio).
} 
I think about the value of alternative methodologies-feminists, intersectional, Indigenous, decolonial, anti-oppressive-as helpful to situate not only multiple representations that qualitative research requires, but also for promoting innovative dynamics to interact with the different actors involved-including our own reflectivity-along the process to produce knowledge.

As I walk, I listen, remember, feel and look at the space in which each meeting took place, the emotions triggered, the discussions opened. I listen and confirm the importance of exposing widely the stories of the Indigenous women that I talked to. Our encounters, our differences and commonalities. They must be known. I listen to the deep reflections that emerge from casual conversations, dialogued from similar understandings that somehow weave us together. I recognize also how malleable our perceptions could be, making sense of the changing and fluid positions Willemsen talks about (Willemse, 2014).

I listen to the conversation with Miriam. It took place in Valladolid, Merida while we were eating in the market and then walking through the city, in a kind of a spontaneous and unforeseen "walkshop" (Leach, 2014; Wickson et al., 2015). It was a walk that allowed us to interact, to get inspired, to let ideas flow more freely, to diminish hierarchies (Leach, 2014). The walk extended the time we spent together, contextualized and stimulated our reflections. It gave meaning to Miriam's arguments about the complexities of the Mayan identity: so present and so denied. Her struggle and contributions seek to reposition her mother tongue and culture (Maya) within the university space, where she started working 10 years ago because it is in academia, she said, where graduate studies really count (Uitz, 2019). The master's degree gave her a contract as a full-time teacher at the Universidad de Occidente (UNO), a job that, as she will narrate, she never thought she would be doing.

Valladolid is a small city of little more than $1000 \mathrm{~km}^{2}$ inhabited by about 75,000 people, of which more than 55,000 speak Maya (INEGI, 2020). The Mexican syncretism, characterized by the cultural mix of the original peoples and the Spanish colony, has the shape of cenotes, a central plaza with a church and an archaeological zone, summarizing the historical condensation of an Indigenous region on which the colonial structure was imposed. It is an overlap that is noticeable in its streets, in the urban layout, in the denial of its inhabitants by their origin; but it is the power of that denied culture that is imposed on the faces and bodies that walked through it-their clothing, the food that is consumed-which defines it. 
The materiality of the landscape was a reference that facilitated the reflection (Wickson et al., 2015: 245). Walking it, feeling it and knowing it by the hand of Miriam, allowed me to contextualize her frustrations and the dimensions of her struggles.

\section{Valladolid, October 9, 2019}

\section{Walking Conversation}

I arrived in Valladolid with another participant in my research with whom I had spent most of the previous day in Merida-breakfast turned into lunch and between our talks I told her that I would go see Miriam. As they knew each other from IFP-Probepi, she proposed to come with me and convinced a friend of hers to take us. The journey from Merida was around $1.5 \mathrm{~h}$, during which we continued the conversation that extended our meeting: the topic was racism within the higher education system. Along the trip we couldn't talk much because it was better to have the windows open and let our voices disappear with the air, than to be suffocated with the humidity of the Yucatecan tropics. The car was old and the air conditioning didn't work.

We met Miriam on a corner at the outskirts of the city. She parked her car and when she got out, we hugged each other fondly. Since she applied for a scholarship in 2004 to study visual communication, we have had a good connection. Miriam drives and owns a car, just like Marcela. Perhaps in her case she breaks less with the imaginary of what being Indigenous Mayan means. We didn't talk about it, but in addition to being originally from a more urban community, she is now a professor at a university. Different contexts, different circumstances. Similar exclusions and discriminations, like the racism and the sexism they experience. We went to the market to have lunch. A solid and roofed warehouse opened at its ends, which prevented a greenhouse effect. Miriam and I sat at a separate table from the other two companions so we could talk calmly.

The place was less than suitable. Not only did the opening of the warehouse and the naturally noisy movement of a market prevent us from being able to speak with that expected calm, but, as soon as we sat down, the tambora ${ }^{17}$ started. I turned on my cell phone recorder. Miriam took it and placed it next to her, a gesture that demonstrated her experience

${ }^{17}$ The tambora is an instrument (drum and cymbals) and a type of music from the North of the country characterized by its percussion sound. 
as a communicator. While we ate, we talked a bit about her experience finishing her master's degree at the University of Deusto, in Spain. Since we had to shout and get close to each other, we decided to get out of there. We went for a walk.

We went to the cenote that is in the middle of the city. It is a majestic expression of nature and of the sacred power of the Indigenous cosmogony: holistic and rooted in the earth; but also, an expression of the privatization projects that manipulate symbols and traditions for the commercialization of tourism. We talked while we walked, we had a sustained intellectual discussion grounded in context (Wickson et al., 2015). The words were connected with the surroundings, with other passers, by the buildings, with the humid, "fresh" air-according to Miriam and the other two companions. The noise and urban movement, the cars, the pedestrians and the irregular sidewalks interrupted the rhythm of our ideas. Cut out and in pieces, they still became deep and solid reflections on the troubles of her professional trajectory.

On the one hand, pursing her graduate studies meant leaving Yucatan and learning about other realities and other struggles that helped her to reference her own. She learned from the Basques to defend her identity on a daily basis: by using the language, eating the food, by taking care of her territory. However, her professional development after the master's degree took her into a different direction. She couldn't go back to the work where she had been promised a place. She was hired for a time in the same organization but as part of the institution's language catalogue (Uitz, 2019). She speaks with anger and disappointment:

They did not recognize my knowledge and skills as an audio-visual producer or as a communicator, but only as a Mayan-speaking woman. Institutions that call themselves intercultural or inclusive value only the Indigenous belonging not the Indigenous professional. (Uitz, 2019)

She told me that her dreams fell apart because she didn't have the right networks and because, she said, "I was nobody's daughter" "There is no graduate degree that compares with networks. Neither the title, nor the experience, or the social commitment could face the institutional interests and favouritism" (Uitz, 2019). She moved to the academy. A foreign world that she never thought to work in but that has allowed her to do what she loves most: audio-visual and radio production in Mayan, by and 
for Mayan people. It was the academic environment that recognized her capacities and gave value to her studies. It seems that universities are a business that produces and feeds on itself, we both concluded.

After the walk, in which we stopped to buy pastries and local products, Miriam invited us to her home to meet her family, consisting of her husband and two little ones. She seemed proud of her family project, but also of the physical space that she and her husband built. We had a glass of water and headed back to Merida, it was already dark and we still had almost two hours of driving. Opening the doors of her home was a caress to the heart, a bridge of affection that has no return.

A year later, while walking through the woods in The Netherlands, I was again thinking about the complexities of a highly educated Mayan (Indigenous) woman like Miriam. Successful and with some professional and economic stability, her journey has been painful due to the structural discriminations of a racist system that, despite its discourses of inclusion and diversity, deepens inequalities. Nonetheless, the strategies she uses to strengthen her language and culture begin at home with her children and are extended to her students and to the university where she teaches. The effect is manifold. It does not erase, however, the pain and the frustration due the racism and tokenism ${ }^{18}$ rooted in many "intercultural" institutions in Mexico. Her shared experience has made me question the expectations about graduate education to overcome certain exclusions Indigenous women face at the core of my Ph.D. research.

Only by having a face-to-face reflective conversation, with a contextual walk, and honestly trying to bridge those who we were in 2004 when we first met, and those who we are now, the story could go the way it went. Only because of sharing, caring and connecting we continue developing projects together. ${ }^{19}$ Thanks to getting inspired by our walking

${ }^{18}$ Making superficial or symbolic efforts to represent people from under-represented groups in certain spaces, policies, etc., in order to give the impression of sexual or racial inclusion and equality.

${ }^{19}$ At the end of 2020 , we participated, together with other women who have collaborated in my Ph.D. research, in a Campaign of Actions in Internet against Racism, sponsored by Cátedra UNESCO in Higher Education and Indigenous and Afro- descendant Peoples in Latin America. As a result of that coalition and with the help of the Associate Professor Dr. Rosalba Icaza, ISS-EUR granted us funds to create a blog and write a book about racism and sexism in higher education. The blog was launched in March 2021 (http://racismo2021.wixsite.com/mujeres-indigenas) and the book will be released in 2022 . 
in Valladolid, I decided to do a similar exercise to think about all those encounters that happened as part of my research, which, in the middle of the Covid-19 pandemic, seemed so far away. I realized then, also walking, that I have been using, developing what in academia would be considered an alternative methodology, which I consider as grounded in my feminist perspective of life.

\section{Adjusting the Research, Placing Care at the Centre}

I hope these narratives were inspiring enough to see some aspects that I would like to discuss further. They are different in their extension, in the analytical elements offered, in the times and emotions with which they were written. Selecting them to be included in this chapter-among the 17 narratives-implied thinking about why these and not others. What have I wanted to convey? I chose them for two main reasons and an extra consideration. First, they are the most evocative for the purpose of this chapter, which is about sharing what I consider a feminist methodology centred in caring. Secondly, because they represent the mentioned changing and fluid positions in/of the research process. The former leans on descriptive details of the encounters - the contexts, the gazes, the food, the decisions taken, the emotions triggered-as key elements to frame a thoughtful process of knowledge production. The latter reflects my own inspirations stimulated differently-one immediately after a gathering, the other months later, in different setting, moved by other emotions. Not all the 17 encounters and the related reflections, I must admit, were so evocative, so inspirational. The third consideration that was important to take into account, was the closeness, the trust, and the availability/willingness of the protagonists to read, comment and give feedback to the text. They were interested in discussing the chapter. They wanted to collaborate. Without their approval I would not have included them here; because my understanding of feminist and Indigenous approaches, as shared here, considers reciprocal, ethical, relational responsibility and respect (Wilson, 2008).

Marcela and Miriam allowed me to use their stories. We agreed that they would be recognized, without pseudonyms, as part of the relational responsibility of collaborative knowledge production and also in order to position them as the protagonists of those stories (Wilson, 2008: 10). As a mestizo/white woman in coalition with Indigenous women we 
are revealing together exclusions, inequalities, injustices. We are exposing resistances and resignifications. They, as Indigenous women professionals are using this (international) space to expose those exclusions, inequalities and injustices in order to position themselves and share their critical perspectives.

Before writing the first draft of this chapter, I sent them, separately, the texts I wrote about our encounters. I wanted them to know how I felt, what our conversations triggered in me and the relevance of our discussions for my research - not for the methodology but as food for thought. I asked them afterwards if I could use them to write this chapter. They both agreed. The texts were in Spanish, that besides being our common language is the one in which I think feel and dream. The need to share the following drafts with them was an excuse, and has become an opportunity to keep writing in my mother tongue. ${ }^{20}$ I have discovered how comfortable the writing process could be, how meaningful the words are when coming from the heart. This exercise has been crucial to develop a collective text, but also to find my own voice as a researcher. The processes of critical reflexivity (Rose, 1997) from which to position ourselves, are constant, permanent, collective and individual. My own reflective exercise, I realize now, started in 2001 but it has been over time, with the Ph.D. journey specifically, that I have found words to name and express my concerns, to set and contextualize the problem.

As I have said at the beginning of this chapter, the initial objective of my research was to know the stories and perspectives on graduate education of a group of professional Indigenous women, and to expose the structural barriers (racism, sexism and classism) they have faced despite their academic education. Situated, contextual, intersectional research based on feminist methodologies of care and collaboration has been key to framing, developing and to being coherent in the representations that I seek to make. Undoubtedly, it is the women's experiences, ideas, indignations, resistances, struggles and resignifications that have been the substance of my work. It was with them that I have spoken; it was from their gazes that I built the central arguments. It was the need to show the exclusions of the colonial and patriarchal system that persists in Mexico that inspired me to do this work. This research is about them because

\footnotetext{
${ }^{20}$ The Ph.D. is in English thus the language in which I am writing my doctoral dissertation.
} 
it is them-their voices and trajectories-who must be recognized as producers of debates, actions and social changes.

However, this initial objective-product of my personal intentionshas been adjusted and complemented as part of the methodology used, that of which knowledge is produced from within, from shared concerns. The centre has moved from exclusively addressing the difficulties they have faced (exclusions, oppressions), to looking into their resistances. "We don't want to be the victims of our own stories" several agreed. On the contrary. As coalition, we would like to challenge what, according to Wilson (2018), Western academia tends to replicate: research focused on the problems of Indigenous populations [on disease rather than health] that serve to impose external solutions and reproduce negative stereotypes (Wilson, 2018: 16).

Therefore, and as part of the collaborative, respectful and caring methodological processes that I believe in and that I have developed, I have adjusted my centre to their centre and created also a common one. One that, while exposing the inequalities and structural exclusions of Mexico, makes visible the roles of the Indigenous women as political and social actors in the new narratives about women. It is their path that holds resistances, transformations and repositions as women, as Indigenous people and as professionals. While promoting their own, they question it. While resisting "the normative", the Western, the patriarchy, the oppressive, they use it to rethink the local, the community. In my experience, then, to be able to shift the centre of a study is necessary to be flexible and humble about our limitations as researchers. It is necessary as well to listen, to pay attention, to care, not only about our individual academic objective, but about the people involved, the processes triggered.

But what does it mean in academia, a world where knowledge is generally produced from the "objective"-meaning "exclusive" and "superior"-view of the researcher, to talk about collaboration and caring? Caring was part of looking at my research as a "ceremony" (Wilson, 2008) which is part of a collective dynamic that, as in a ceremony, seeks to produce and bond relationships responsible of themselves and among themselves (Wilson, 2008: 7-8). In its attempt to be honest and attached as much as possible to the multiple representation that entails, the research was not free from inconsistencies and errors. It was also that 
intention which led me to validate each text, each story, each representation with the protagonists and produce something that, even though it is my responsibility, was shaped by the participants.

Along my methodological reflections about caring, I also came across with a nuance that I consider important to differentiate here. One has to do with the forms of producing knowledge as well as its translation into academic language; and the other has to do with the substance, with those concerns-discomforts-that drive us to look more deeply at a social problem. Caring in terms of forms refers, I consider, to the written production and the process that it entails: the importance of respecting the ideas of the collaborators, as well as recognizingnaming - the bodies, the stories, the contexts that build them. The forms consider paying attention to ethical aspects of confidentiality and security of each participant and follow institutional regulations to guarantee the proper use of the information generated. ${ }^{21}$

As for caring in terms of substance, I mean the foundation, the origin that leads us to carry out an investigation and that has to do with that social problem we are interested in exposing, questioning, solving. It is this ground that must be linked or shared with those who are part of the research and from where to seek a meeting point to reflect together. In other words, what is important in the research process is what motivates it, and how that curiosity, that discomfort, that dissatisfaction or that social concern arises and is echoed among researchers and (potential) collaborators or participants.

Although my research began with a specific personal objective, the methodological process has taken me much further. I think that on the one hand it has been a valuable contribution to, among other things, promoting what Hooks (2015) calls "talk [about] race". That is to say, a political struggle to expose and position the own perspectives and voices of Indigenous women, as a contribution to a still missing body-under construction, I would say-of social and political criticism of racialized women on racism (Hooks, 2015) and other exclusions. But on the other hand, and more important methodologically speaking, to try to build collectively, recognizing our individualities within the set of voices that

${ }^{21}$ As an example, after having systematized the conversations with the 17 participants, I organized three online conversations to present preliminary results and reflections. Their suggestions, comments and opinions were useful to rethink and adjust some of the ideas or concepts raised. 
we are and openly share the reflective processes that we deal with. It is about constructing knowledge that roots and shapes us as conscious social beings, critical of a reality that we must transform so that we all have a worthy place in it.

To talk about collaboration, care and respect as the backbone of my research has been talking about everybody, about them, about me, about us. It has been about sharing, about taking individual and collective decisions; about interpreting silences, complicities. It has been about putting ourselves as women at the centre: various, diverse, opposed, partisan, in coalition. It has been an exercise of imbalances and inconsistencies, but by identifying and naming them I have tried assume them. Thinking about the possibility of producing knowledge based on these three principles has been encouraging. They are values that emerge from feminist approaches in manifold ways. Approaches that are teaching us to look at and recognize privileges, work with them; to look at the pains and take care of them; to look at ourselves, value our contributions. I am learning to think from all of these. From there, I am sharing my experience, hoping to continue challenging, transforming conventional methodologies and the exclusions they entail.

Acknowledgements I want to deeply thank Miriam Uitz and Marcela Avella for having helped me to build this text. Not only did they give me the encounters that I describe and without which my arguments would not make sense. They are enough for me to look at life differently. They have also been generous in reviewing my ideas, clarifying some of their inconsistencies. Above all, I thank them for allowing me to stay close. That Marce shares her photos of those coffee seeds turned into "little soldiers" and "butterflies" that years later will reach a cup of BI'AVELLA. That Miri tells me about her family entrepreneurship and makes me carve for the fried bananas (Don Ja'as) they distribute around Valladolid. That I can share with them how my children are growing; what The Netherlands is like. I thank them simply for being a part of my life.

\section{REFERENCES}

Aguilar Gil, Y. (2020, Abri 24). Aquí ("Here"). Revista de la Universidad de México. Especial: Diario de la pandemia. Retrieved January 2021, from https://www.revistadelauniversidad.mx/articles/fa2c8cea-aecc474e-a8aa-2831b86f0078/aqui.

Ahmed, S. (2017). Living a feminist life. Duke University Press. 
Avella, Marcela. (2019, November). Reflective conversation (audio). Oaxaca, Mexico.

Brown, L., \& Strega, S. (2005). Research as resistance. Critical, indigenous and anti-oppressive approaches. Canadian Scholars' Press.

Collins, P. H. (2000). Black feminist thought: Knowledge, consciousness, and the politics of empowerment. Routledge.

Crenshaw, K. (1989). Demarginalizing the intersection of race and sex: A black feminist critique of antidiscrimination doctrine, feminist theory and antiracist politics. The University of Chicago Legal Forum.

El Economista. (2018). Dos de cada diez mexicanos se asumen indigenas ("Two out of every ten Mexicans consider themselves indigenous"). Retrieved February 2021, from https://www.eleconomista.com.mx/politica/Dos-decada-10-mexicanos-se-asumen-indigenas-20181212-0049.html.

Haraway, D. (1988). Situated knowledges: The question in feminism and the privilege of partial perspective. Feminist Studies, 14(3), 575-599.

Harding, S. (1991). Whose science? Whose knowledge? Thinking from women's lives. Cornell University Press.

Hooks, B. (1995). Killing rage. Ending racism. Henry Holt and Company.

Hooks, B. (2015). Feminist theory. From margin to center. Routledge.

INEGI (Instituto Nacional de Información, Estadística y Geografía). (2020). Retrieved December 7, 2020, from https://www.inegi.org.mx/app/bus cador/default.html?q=poblacion+indigena\#tabMCcollapse-Indicadores.

Leach, M. (2014). The wonder of walkshops. Retrieved March 2021, from https://steps-centre.org/blog/wonders-walkshops/.

Mignolo, W. (2011). The darker side of western modernity. Global futures, decolonial options. Duke University Press.

Morgan, G. (1983). Beyond method. Strategies for social research. SAGE Publications.

Puwar, N. (2004). Space invaders. Race, gender and bodies out of place. Berg.

Rose, G. (1997). Situating knowledges: Positionalities, reflexivities and other tactics. Progress in Human Geography, 21(3), 305-320.

Smith, L. T. (2012). Decolonizing methodologies. Research and indigenous peoples. Zed Books/Otago University Press.

Uitz, Miriam. (2019, October 9). Reflective conversation during fieldwork (audio). Valladolid, Yucatan, Mexico.

Walsh, C., Schiwy, F., \& Castro-Gómez, S. (2002). Indisciplinar las ciencias sociales: Geopoliticas del conocimiento y colonialidad del poder. Perspectivas desde lo andino. Universidad Andina Simón Bolívar/Abya-Yala.

Wickson, F., Strand, R., \& Kjølberg, K. L. (2015). The walkshop approach to science and technology ethics. Science and Engineering Ethics, 21, 241-264. 
Willemse, K. (2014). "Everything I told you was true": The biographic narrative as a method of critical feminist knowledge production. Women's Studies International Forum, 43, 38-49.

Wilson, S. (2008). Research is ceremony indigenous research methods. Fernwood Publishing.

Open Access This chapter is distributed under the terms of the Creative Commons Attribution 4.0 International License (http://creativecommons.org/ licenses/by/4.0/), which permits use, duplication, adaptation, distribution and reproduction in any medium or format, as long as you give appropriate credit to the original author(s) and the source, a link is provided to the Creative Commons license and any changes made are indicated.

The images or other third party material in this chapter are included in the work's Creative Commons license, unless indicated otherwise in the credit line; if such material is not included in the work's Creative Commons license and the respective action is not permitted by statutory regulation, users will need to obtain permission from the license holder to duplicate, adapt or reproduce the material.

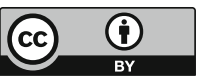

